\title{
Disclosure of Financial Information - Are New Zealand Employees and Unions Missing Out?
}

\author{
Judy Brown*
}

New Zealand policymakers have to date paid scant attention to the disclosure of financial information to employees and unions. However, there are signs this could change. Current trends under the Employment Contracts Act towards enterprise and productivity bargaining may well see access to financial information emerge as a domain of increasing interest and significance. The Labour Party's policies for industrial relations reform incorporate proposals for a good faith bargaining requirement, including a statutory duty to supply relevant information. Should any future government contemplate action on industrial democracy, this would also have implications for disclosure. This paper examines existing legislative requirements in the United States, United Kingdom and Europe. It is suggested that these provide a useful starting point for those interested in pursuing some New Zealand disclosure initiatives and that some valuable lessons can be drawn from overseas experiences.

\section{Introduction}

The regulated disclosure of financial information in Australasia is firmly aimed at the capital markets. In New Zealand, companies seeking to raise debt or equity funds from the public are required to provide a variety of financial disclosures under the Securities Act 1978. The Companies Act 1993 and Financial Reporting Act 1993 require "issuers" (those companies who have allotted securities to the public) to supply all shareholders with audited annual accounts at least once every year. These accounts must comply with "generally accepted accounting practice" (approved financial reporting standards or, where there is no applicable standard, policies having "authoritative support" within the accounting profession in New Zealand). Companies that have their shares listed on the NZ Stock Exchange must produce half-yearly reports, preliminary final statements and audited annual reports drawn up in accordance with approved standards. Very similar requirements are provided under Australian securities and companies legislation.

* Senior Lecturer, Accountancy Group, Victoria University of Wellington. The author would like to thank anonymous Journal referees for their helpful comments. 
Disclosure in the context of the labour market, on the other hand, remains a purely voluntary affair. New Zealand and Australian employers are under no statutory duty to provide financial information to employees or their representatives for collective bargaining or any other purposes. Companies legislation in New Zealand has recently been subject to a major review exercise. However, no amendments were included in the Companies Act 1993 or in the new Financial Reporting Act 1993 that would change this situation. The interests of the suppliers of financial capital remain the only ones deemed worthy of statutory protection ${ }^{1}$. Similarly, the issue of information rights appears to have eluded drafters of the Employment Contracts Act 1991.

The suggestion is sometimes made that labour interests can simply "make do" by relying on the statutory reports produced for shareholders ${ }^{2}$. There are three major difficulties with this:

(a) It totally overlooks that the majority of employees are employed by companies that do not raise debt and equity funds from the public ${ }^{3}$. Non-public issuers must still prepare financial statements but are not required to disclose publicly any information relating to their finances and may dispense with an audit if all shareholders agree. In addition, under the Financial Reporting Act 1993, "exempt" companies (those with assets not exceeding

Indeed the whole issue of employee rights in general and the accountability of companies to the public was conspicuous by its absence. Some measure of lack of interest can be gauged from the NZ Law Commission's preliminary discussion paper on company law reform (NZ Law Commission, 1987), in which one paragraph (para.40) was devoted to the duties of a company to its employees and the public at large. The Commission recommended that a requirement under the old Companies Act (s.133) for public companies to file a copy of their financial statements with the Companies Office for public inspection (which presumably did imply some notion of a broader accountability) be discontinued on the grounds that "the costs exceeded the benefits". The Commission found it "difficult to discern any independent public interest" in disclosure "beyond identification of the company and its responsible officers" (para.125). (In the event, s.18 of the Financial Reporting Act 1993 still requires public disclosure of the accounts of publicly listed companies). The writer understands that the NZ Council of Trade Unions (NZCTU) did make an approach to the Law Commission with the aim, inter alia, of raising the issue of disclosure rights for workers but was informed that the Commission regarded that as a matter for labour law not company law (a similar reaction to that received by the United Kingdom union movement 30 years ago). In its 1989 Report on the reforms, the Commission reiterates its view that "a Companies Act is not the appropriate vehicle for imposition of general social reforms" (NZ Law Commission, 1989: para.19).

The NZ Society of Accountants, for example, accepts that an entity's responsibility to report publicly is broader than its "legal" obligation. It regards the financial reports of public issuers as "general purpose financial reports" intended to meet the needs of external users "who are unable to require, or contract for, the preparation of special reports to meet their specific information needs" (NZSA, 1993: para.1.5). In the initial Exposure Draft of its Statement of Concepts, employees were specifically mentioned as one such user group. Interestingly, this reference was dropped in the final draft although the Statement still talks more generally about those "providing resources" to entities.

According to the NZ Law Commission (1989: para.17) "much less than one percent of companies raise capital from the public", with listed companies accounting for only 209 of the approximately $150,000 \mathrm{New}$ Zealand registered companies. 
$\$ 450,000$ and turnover not exceeding $\$ 1$ million) are not required to comply with financial reporting standards. Exemptions from all or part of particular accounting standards are also available to certain other non-public issuers under the NZ Society of Accountants' Framework for Differential Reporting. This framework emphasises still further the concentration on shareholder needs, with the "separation of owners and governing bodies" providing one of the three criteria for determining whether a company may claim exemptions.

(b) Listed companies typically comprise complex structures of subsidiaries and subsubsidiaries. In these situations, consolidated accounts are prepared which present the results and financial position of the group of companies as though it was a single enterprise. Thus, for example, the annual reports of Fletcher Challenge Ltd incorporate, inter alia, the results of Crown Forest, Fletcher Construction and Petrocorp. Consolidated accounts are useful to labour interests, for example, as a measure of a group's ability to sustain short-term losses in a particular area. At the same time, because they contain very general information, they are usually of limited value in answering questions about an individual enterprise or bargaining unit. Individual subsidiaries do continue to prepare their own accounts. However the bulk of subsidiaries controlled by listed companies are not public issuers and their accounts are not freely available.

(c) Even leaving aside access difficulties, the interests and priorities of capital and labour and hence their information needs differ. The argument that workers need, or indeed have a right to, financial information rests on a pluralist conception of organisations and centres around three main themes: strengthening managerial accountability, wage bargaining and industrial democracy initiatives (for further background and detailed discussion of these points, see Brown, 1992). From labour's point of view, profit is not a sufficient expression of the success of an enterprise. Corporate reports rarely contain substantive information relating to the workforce, for example, on such matters as labour productivity, the range of incomes, fringe benefits, superannuation contributions, maintenance of employee purchasing power, transfer pricing policies, levels and locations of employment, skills training or health and safety records. Moves towards a broader set of performance measures in annual reports could help to secure increased accountability of management to employees and various other non-shareholder constituencies. External reporting also offers the advantage of building up a systematic public record for analysis and comparison (Owen and Harte, 1984). However, such reports are never likely to be timely nor disaggregated enough for wage contract or other bargaining purposes. The needs of bargaining agents are in many respects more akin to those of bankers or Inland Revenue who rely on special purpose financial reports.

Since the 1970s a number of companies in New Zealand have adopted a practice of preparing specialised annual reports for employees (Smith, 1985). However, in the absence of specific statutory requirements or agreed accounting standards, companies are free to decide for themselves the most appropriate form and content of these reports. In practice, they typically 
contain only very simplified financial information and rarely allow for any meaningful analysis They have the added drawback of being unaudited so that users are provided with little assurance about the credibility of the information being reported. The NZCTU (1989: 17) understandably regards such reports as owing more to a "corporate relations gimmick" than to genuine concepts of "information sharing or participation".

During the late 1980s/early 1990s recessionary economic conditions and moves toward enterprise bargaining also saw employers drawing attention to their financial situation to justify redundancies, closures and lower wage settlements:

The Christchurch Star, which slashed its workforce by 40 percent yesterday, was losing $\$ 350,000$ a month, the daily evening newspaper's chairman, David Stock, said (Dominion, 27 November 1990).

Workers at James Smiths in Lower Hutt have been told this week the store will close ... Staff were given no warning of the closure and were stunned to hear about it on Tuesday. They were told the "auditor said it's best", she said (Redundant worker, Dominion, 19 March 1992).

Employees squeezing their employers into expensive (wage) settlements will find that those settlements impact on the competitive position of the employer - jeopardising their own job security. The driving force for employers had to be their financial position . . . (NZ Employers Federation chief executive Steve Marshall, Dominion, 23 July 1992).

Unions were frequently criticised for attempting to make wage settlements without sufficient regard to the economic consequences for the undertaking. The NZEF (1989: 15) wanted industrial relations to "become more a matter of the economic concerns of employer and employee and the organisation in which they are both concerned" and to be "conducted in a more rational and harmonious way". The NZ Business Roundtable (1989: 2) endorsed such an approach and observed that in "good employment relationships" employees would be "fairly rewarded for their efforts". Assuming (somewhat optimistically) that employees and labour representatives agree that a "fair" reward is one which results from the "free play" of market forces and contracts based on the financial circumstances of the individual firm, it is difficult to see how "rational" workplace bargaining can take place or how employees can judge whether they have been "fairly rewarded" without their having rights of access to financial information. It seems both unrealistic and unreasonable to expect one party to bargain from a position of ignorance. Moreover to suggest, as the NZEF (1989: 17) did, that the recovery of the New Zealand economy depended upon profits being appropriated for "capital formation" rather than "wages or conditions" was implicitly asking workers for some form of investment which, even on the narrowest view, presumably entitled them to be treated as "owners" with information rights.

With corporate profits on the rebound, employers seem less enthusiastic about admitting ability to pay considerations into wage bargaining. In early 1994, the NZCTU queried where "the workers' share of the economic recovery was" after statistics indicated that average hourly pay rates barely moved in the previous year (NZ Herald, 24 February 1994). NZCTU President Ken 
Douglas compared wage growth with "obscene profit gorging" by large companies, for example, Telecom (up nine percent in the final quarter of 1993), Air NZ (up 45 percent in the last half year) and INL (up 32 percent for the half year). The following day Telecom announced that it would "listen to the workers' claims" but believed that "pay rises on the basis of inflation, company profit or productivity" were "out of date" (NZ Herald, 25 February 1994). The preference now seems to be for more individually based forms of "merit pay".

During the 1990s interest in "employee communications" programmes has also been evident with the spread of ideas propounded by HRM theorists (Townley, 1989; Storey, 1992). Some companies have established workplace consultative committees and undertaken to provide "relevant information" to facilitate consultation between management and labour. However, again, it seems that the decision as to what constitutes "relevant information" still lies primarily with the employer and there will be little worker representatives can do if a company refuses to disclose information voluntarily. This may change in any Labour-led coalition government. The Labour Party's policy for industrial relations reform incorporates proposals for the introduction of a "good faith bargaining" requirement, including a statutory duty to provide relevant information. According to the Rt Hon. Helen Clark, it is envisaged that information requirements "will be spelt out in some detail and provision made for the swift resolution of disputes as to what information is to be made available to the parties" (Clark, 1993: 158). Should Labour choose to reactivate the recommendations of its 1988 Committee of Inquiry into Industrial Democracy, this would also have implications for disclosure (see Report of the CIID, 1989: 305); effective worker participation inevitably requires access to internal management accounting data.

At present, however, disclosure to unions and employees in New Zealand and Australia remains solely a matter of managerial prerogative or, at best, the subject of private contracting between employer and employee groups. This "voluntarist" approach is in marked contrast to the situation that exists in the United States, United Kingdom and throughout Europe where labour law imposes duties on employers to supply worker representatives with a range of both general and special purpose financial information.

\section{United States}

The United States has no statutes dealing directly with the disclosure of information to employees and their representatives. However, the National Labor Relations Act 1935 (NLRA) imposes on employers and unions a duty to bargain in good faith. Case law, evolving since the mid-1930s, has established that this requirement gives unions the right to request from employers information which is "relevant and necessary" to mandatory subjects of bargaining (wages, hours and other terms and conditions of employment). A United Kingdom Commission of Industrial Relations (1972: 37) noted that the underlying philosophy is that: 
... without such information the union, as bargaining agent, would be unable to perform its duties properly and the employer's refusal to supply information is as much a violation of the duty to bargain in good faith as if he had failed to meet and confer with the union.

The question of "relevant and necessary" information has been the subject of numerous National Labor Relations Board (NLRB) and court rulings. Information concerning wage rates, incentive earnings, hours worked and job evaluation criteria are considered to be presumptively relevant to the union's role as bargaining agent. The decentralised nature of collective bargaining in the United States means such information must generally be made available at plant level. Access to comparative earnings data for other groups of workers is sometimes also granted. The custom of bargaining over fringe benefits has also given unions access to information concerning the operation of health insurance and pension schemes.

The phrase "relevant and necessary" has been interpreted more restrictively with respect to details of the employer's profits and other aspects of its financial situation. In NLRB $v$ Truitt Manufacturing Co. (1956) the Supreme Court confirmed that as a general principle an employer cannot argue "inability to pay" to counter a union demand, and then refuse to supply financial information to substantiate its claim. The Court stated that if an inability to pay argument "is important enough to present . . . it is important enough to require some sort of proof of its accuracy". This decision has been extended to cases where employers assert that general economic conditions dictate their position. In Cincinnati Cordage and Paper Co. (1963), the NLRB held that the company's contention that it could not pay a wage increase and "stay competitive" was tantamount to a claim of "inability to pay" and that the Truitt rule regarding the provision of substantiating information applied. ${ }^{4}$

The ruling in Truitt has given unions access to breakdowns of manufacturing costs including wages, raw materials, salaries, depreciation, and overheads and to information about incoming and outgoing orders. However, in the absence of financial inability or similar claim, a union has no presumptive right of access to such information. The employer must concur before ability to pay is accepted as a relevant consideration. Thus where rejection of a wage demand is based on unwillingness rather than inability to pay there is no obligation to disclose, a situation unionists regard as grossly inequitable:

companies that are unprofitable and financially weak are often quick to disclose all the pertinent information since it helps their cause. Financially strong companies, however, do not cry poverty or an inability to meet the union's demands and thereby escape the obligation to open their books (union official cited in Jain, 1981: 756).

Disclosure rights apply to the administration of existing contracts as well as to the negotiation of future agreements. Information supplied must allow the bargaining agent to "understand and discuss intelligently" the issues raised in bargaining. It must be made available promptly and in

4

It should be noted that a simple disinclination to pay does not result in an obligation to disclose financial information. 
a form which is reasonably useful and "not so burdensome or time consuming as to impede the process of bargaining" (Old Line Life Insurance Co. 1951) although not necessarily in the form requested by the union.

Unions are not entifled to demand disclosure of information related to permissive subjects of bargaining (those over which parties may but do not have to bargain). This constraint flows from judicial acceptance of capital and managerial prerogatives and means unions are generally unable to review strategic management accounting information. Issues relating to the long-term planning of the enterprise - capital investment plans, plant location, product diversification, and so on are deemed to impinge only indirectly on the employment relationship and are, therefore, not mandatory subjects of bargaining. Similarly, decisions to close all or part of a company are not subject to mandatory bargaining because such decisions are held to lie "at the core of entrepreneurial control" (Fibreboard Paper Products Ltd v NLRB 1964). That the employment implications of such decisions often lie "at the core of worker and union concern" appears by and large to be ignored:

\begin{abstract}
Decisions to continue subcontracting, to close one of several plants, to build a new plant, to liquidate assets, to sell part or all of the enterprise, or to become part of a conglomerate are all decisions which may be more important to the employees than wages or hours of work. Nevertheless, the courts have held that the employees have no right to be notified, no right to discuss, and no right to use their concerted efforts to affect these types of decisions. The impact on the employees' livelihoods and their futures may be far greater than the impact on the stockholders or management, but employees have no voice. They do not even have a right to know the business facts on which the decision was based; they are told only of the consequences which they must bear because of a unilateral management decision (Summers cited in Atleson, 1983: 6-7).
\end{abstract}

The NLRB has also noted that decisions "in which a significant investment or withdrawal of capital will affect the scope and ultimate direction of the enterprise" are matters "essentially financial and managerial in nature" and involve "subject areas as to which determinative financial and operational considerations are likely to be unfamiliar to the employees and their representatives" (Atleson, 1983: 130-1, emphasis added). The implicit assumption is that unions are not only "too ill-equipped to deal with such complex and weighty matters" (ibid: 131) but that financial decisions are essentially technical matters best left to the "experts".

An employer may refuse to disclose "relevant and necessary" information on the grounds of commercial confidentiality or the need to protect individual privacy. In International Woodworkers $v$ NLRB (1959) the Court of Appeal refused union access to production and sales information on the grounds that its release might have a detrimental effect on the competitive position of the employer. Since the 1979 Supreme Court decision in Detroit Edison, the NLRB has taken the position that an employer's interest in refusing to disclose on confidentiality grounds must be "legitimate and substantial". The employer must also make a "good faith" effort to provide the union with the data required in an alternative form designed to protect the employer's interests while at the same time meeting the union's needs. 
A disclosure request can also be refused on the grounds that the union's request is motivated solely by a desire to harass management or that the employer would have to go to "unreasonable" lengths to comply with the union's request (Whitin Machine Works 1955). For example, if the company does not normally prepare quarterly or half-yearly reports it is not obliged to start doing so (McLean-Arkansas Lumber Co. 1954).

While employers may be required to produce certain information, they may do so in specially prepared, unaudited reports. The union has no automatic right to inspect original documents or to appoint its own auditor (Jacobs Manufacturing Co. 1951). This is in marked contrast to the situation of the auditor acting on behalf of shareholders who has rights to examine all original documents. Where rights of access to original documentation are granted, the employer may insist that the accountant not be in the union's general employ (Yakima Frozen Foods 1961).

Given the inability to subject employer submissions to independent analysis, it is perhaps not surprising that some unionists remain wary of active participation in financial disclosure. Union representatives surveyed by Palmer (1977: 32-3) complained that information was often not forthcoming without an NLRB "unfair practices" threat and that "often the clarity, format, usefulness and reliability of the information were poor". The most frequently mentioned specific criticisms related to "incomplete information, selective disclosure of results and deceptive practices in accounting". The union representatives expressed a strong preference for the availability of financial information that was "independently audited ... provided on an ongoing basis rather than only at contract bargaining time" and provided "non-selectively" in years of high and low profitability.

If an employer refuses to disclose information, the union has a right to file a complaint with the NLRB alleging that the employer is guilty of an unfair labour practice. Rulings of the Board do not carry the force of law and, if not accepted, must be advanced through the court system. Although the limits have been drawn tightly, United States employers are reported to regard the NLRB's general posture on disclosure as an invasion of managerial prerogatives (Foley and Maunders, 1977: 4). Unions have complained that employers fail "to meet even limited NLRB disclosure requirements" and that they are unable to correct this situation due to the time required to process an NLRB complaint (Palmer, 1977: 33).

\section{United Kingdom}

Compared with the situation in the United States and in Europe, the regulated disclosure of information to labour representatives in the United Kingdom is a relatively recent phenomenon. Statutory provisions were first introduced in the Industrial Relations Bill just before the Labour Government left office in 1970 . Very similar provisions were subsequently enacted by the Conservative Government in the Industrial Relations Act 1971 but never became operative before they were repealed by the Trade Unions and Labour Relations Act 1974. The current law on disclosure is as set out in the Employment Protection Act introduced by the Labour Government 
in 1975 and now incorporated in the Trade Union and Labour Relations (Consolidation) Act 1992 (TULRCA). It remains substantially along the lines of the 1971 Act.

Section 181 of the TULRCA imposes a duty on employers at all stages of collective bargaining to disclose to recognised trade union representatives, on request, information:

without which the trade union representatives would be to a material extent impeded in carrying on ... collective bargaining, and information which it would be in accordance with good industrial relations practice (to disclose) for the purposes of collective bargaining.

The TULRCA imposes no obligation to disclose any specific item of information. However, the Advisory Conciliation and Arbitration Service (ACAS) has issued a Code of Practice which lists items which might be relevant to collective bargaining. This includes reference to pay and fringe benefits, non-wage labour costs, savings from increased productivity, sales and order book situation, cost structures, gross and net profits, sources of earnings, assets, liabilities, allocation of profits, government financial assistance, transfer prices, intra-group loans and interest charged.

These obligations are, however, limited in various ways under Section 182 of the TULRCA. The employer may refuse to disclose information on the grounds that disclosure would cause "substantial injury" to the firm (for reasons other than its effect on collective bargaining) or that it would involve work or expense out of "reasonable proportion" to its value in collective bargaining. The ACAS Code of Practice envisages that the "substantial injury" exemption might cover situations involving a potential loss of customers to competitors, the withholding of materials by suppliers or the impairment of the ability to raise business finance. Examples of information which might cause substantial injury in these circumstances are given as follows: cost information on individual products, detailed analyses of proposed investments, marketing or pricing policies and the make-up of tender prices.

The employer may also refuse to disclose information on the grounds that it would be against the interests of national security, would contravene an Act of Parliament, was given to the employer in confidence, relates to an individual and consent has not been given to its disclosure or was obtained for use in legal proceedings.

As in the United States, the employer is under no obligation to produce, or allow inspection of, any document other than the one specifically prepared for the purpose of providing the information.

If an employer refuses to disclose information, the union has a right of appeal to the Central Arbitration Committee (CAC). The CAC may refer the matter to the ACAS for conciliation. If this fails, the matter must go to a full, formal hearing. A ruling is then made specifying what, if anything, the employer is required to disclose, and when. If an employer ignores a CAC ruling, the union may present a further complaint to the CAC. If the further complaint is upheld, 
the union can ask the CAC to make an award which, if granted, has effect as a term of contract for each of the individual employees concerned. The award can be retrospective.

In practice, unions have made only limited use of their information rights (Marsh and Hussey, 1980; Gospel and Willman, 1981; Jackson-Cox et al., 1987). The legislation was relatively well used in the first 16 months of its operation, with 74 references to the CAC. The following year the number fell to 38 and this trend has continued with the references in any one year since 1980 rarely exceeding 20 (Industrial Relations Review and Report, 1993). A variety of possible reasons have been offered for this: lack of interest or cynicism about the value of information, satisfaction with current disclosure levels, disenchantment with the legislation and constraints on the effective use of information by unions.

(a) Lack of interest or cynicism about the value of information - this explanation does not appear to be consistent with evidence of union enthusiasm for the concept of increased information disclosure (Trades Union Congress 1974; 1977; 1987). The TUC (1977), for example, recommends that union representatives make use of the disclosure legislation to find out about investment and other company plans and to negotiate information agreements with managements. During the 1970 s, the union movement also made a number of suggestions for improvements in financial reporting methods and actively supported such practices as "value-added reporting". . However Hussey and Marsh (1983) point to the lack of tradition in the United Kingdom of conducting collective bargaining on the basis of detailed financial, production and manpower information. They observe that new styles of "informed bargaining", however strongly supported at head office, may be far from easy to impress on the rank and file. Given that the United Kingdom economy has been in a state of recession for most of the past 15 years, there may have also been an understandable disinclination on the part of unions to actively seek "bad news". Fears of managerial incorporation, the absence of concessions to workplace democracy, scepticism about the credibility and impartiality of "management's facts and figures" and doubts about the independence of the accounting profession may also contribute to an "ostrich approach" to information disclosure (Brown, 1992).

(b) Satisfaction with current disclosure levels - unions may already have access to all the information they believe they need. There is some evidence that the passing of legislation has encouraged companies to adopt more open disclosure policies, without unions having

\footnotetext{
Value-added reporting was quite widespread in the United Kingdom in the 1970s (for detailed background, see Burchell et al., 1985). "Value added" represents a broader concept of "income" than "profit" and is arguably more in keeping with a "stakeholder" theory of the corporation. It takes items like wages and salaries out of the category of costs (which on the face of it are desirable to minimise) and expresses them as a share in the net proceeds of the enterprise. In practice, employers often used these statements to emphasise co-operation and team work in the creation of wealth but, from a pluralist frame of reference, they also offer the advantage of making distributions and re-distributions of wealth within the enterprise more transparent.
} 
to make recourse to the CAC (Dickens, 1980). Information provided voluntarily by employers, together with that obtained from alternative information sources (the media, union members) may be regarded by unions as sufficient for their purposes. Dair and Reeves (1979), for example, report a study of shop stewards who stated they were happy with existing disclosure arrangements and "could think of nothing more to ask beyond what was already being provided by management" (p.25). Of course such professed contentment may not so much point to the adequacy of information levels but rather the limited capacity of shop stewards to identify the specific information which is (or could be) available and which could be of use.

(c) Disenchantment with the legislation - the passing of legislation may have encouraged United Kingdom employers to adopt more open disclosure policies. However predictions that it would be a "relatively simple task for (unions) to push back the frontiers of disclosure" given that they could simply ask for the information they wanted (Hilton, 1978: 5) have proved somewhat premature.

Unions have used the TULRCA provisions to secure access to information on such matters as net and gross profit margins, pricing policies, pay scales, wage bills, numbers employed and training budgets. More recently, the CAC has also accepted that unions require information in order to carry out a monitoring role with respect to the operation of performance-related pay systems and job grading schemes (Industrial Relations Review and Report, 1992). However, in general, employers have been quite successful in limiting the flow of information on the basis of the exemptions provided.

Many employers have objected successfully to disclosures on the grounds of an absence of "material impediment". This has, for example, proved a particular obstacle to unions seeking information they have managed without in the past. Where unions are seen as having alternative means of obtaining the information sought from employers, it has also been held that they are not materially impeded (Clydesdale Bank Ltd and the Association of Scientific, Technical and Managerial Staffs, 1978).

The issue of what constitutes "good industrial relations practice" has also caused difficulty. The CAC does not see its brief in this area in terms of setting new disclosure standards:

We feel that although we may adopt the broad principle that the more information that is disclosed, the better for industrial relations, it is not for us to map out wholly new approaches to collective bargaining. We are not necessarily to seek a type of "general level" of bargaining practice. We are possibly entitled to take the best. We are not, we think, entitled to take one that does not exist, declare it good and enforce it (Standard Telephones and Cables and ASTMS, 1979).

At the same time, the CAC concedes that attempts to articulate a "good industrial relations" standard based on "best practices" have been somewhat hampered by the weak consensus on the issue: "information which is commonly disclosed in one sector of 
industry may be regarded as a highly guarded secret in another" (CAC Annual Report, 1978).

The CAC does appear to take the view that disclosure will not contribute to good practice if it reveals or confirms conflicts of interest. In Daily Telegraph Ltd and Institute of Journalists (1978) the CAC recognised that there was a "real possibility that the very giving of information between combatant parties merely serves to extend the causae belli". In that case disclosure was prescribed in such a manner that it would "cause no sound excuse for a hostile reaction". In Standard Telephones and Cables and ASTMS (1979) the Committee denied union representatives access to information about fringe benefits on the grounds that "such disclosure would actually be productive of strife".

The "substantial injury" clause has also been interpreted widely. Rights to information on segment data, itemised costs, investment policies and plant closures have been rejected on these grounds. Airwork Services and Amalgamated Union of Engineering Workers (1978) concerned a union request for information about the profits of various airfields in England and Scotland. The union submitted that the information was required to enable it to make a wage claim based on the company's profitability and ability to pay. Work at the airfields was awarded through a tendering system and the CAC held that disclosure was likely to severely jeopardise the company's chances of renewing contracts should it fall into the hands of a competitor. An assurance on the part of the union of confidentiality was rejected on the grounds that such confidentiality would be difficult to maintain. In Hoover Ltd and General and Municipal Workers' Union (1979), the CAC agreed that information concerning the company's investment policies, the allocation of production, product line sales, operating costs and contributions was "highly important and relevant" to collective bargaining. However, because the information was also of a sensitive, commercial nature the employer was not obliged to disclose it.

Unions have also experienced difficulties with employers supplying vague and highly aggregated information and/or claiming that requested information is "not collected". When approached by unions requesting details of its cost structures in support of their 1978 wage claim the Ford motor company responded that 68 percent of its costs related to "materials and services" and that a breakdown of this figure was "not available" (Gold et al., 1979: 18).

The ACAS Code has also been criticised for not attempting to list basic items which should be disclosed in all circumstances and for omitting important items, especially on prospective, organisational and international information (ibid: 21 ). In the early 1980s, the ACAS explored the possibility of revising the Code but decided that "the widely divergent views that their preliminary consultations had revealed meant that it would be premature to proceed with the revision at that time" (Jackson-Cox et al., 1987: 198). 
Notions unions might have had about seeking disclosure in support of extensions to collective bargaining (TUC, 1974) have also been thwarted. The CAC has ruled that a union cannot claim a right to information in order to bargain on a subject which has never previously beẹn accepted as a subject for bargaining. Agreement on the part of management to bargain must come first in order to have a disclosure right:

Collective bargaining is limited to workers and matters for which the trade union is recognised... (for example) a claim to bargain upon pensions, where this topic had never previously been an accepted subject of the bargaining process, would fall foul of this provision unless and until the scope of bargaining was extended by agreement to that subject (Daily Telegraph Ltd and Institute of Journalists, 1978).

The TUC-Labour Party Liaison Committee (1982) notes that any legislation on industrial democracy will have to be accompanied by further legislation on disclosure in order to give unions access to information concerning policy and strategy decisions.

The "reasonable cost" clause places unions in the difficult position of having to demonstrate the value of information without having seen it. As Foley and Maunders (1977: 18) observe it is extremely difficult to define ex ante what the value of information will be. Nor is the question of what is an "unreasonable" amount of work or cost involved in making information available self-evident (Marsh and Rosewell, 1976). Unreasonable by whose criteria? The costs of preparing information should generally be quite low since much of the information would, in any case, be available for internal management purposes.

As in the United States, there have been complaints about the lack of access to original documents. The CAC itself appears to feel uncomfortable with the Act's provisions in this respect. In one case it said that notwithstanding that it felt unable to award access to company records "it would be hard to deny the moral and customary right of the (union) to the information required" (Greater London Council and GLC Staff Association and the Union of Construction, Allied Trades and Technicians 1979).

Unions have also complained that the remedies available against employers who refuse to provide information are inadequate (General and Municipal Workers Union, 1978). The complaints procedure is cumbersome and provides employers with plenty of opportunities for procrastination. Unions going through the full procedure face a lengthy waiting period, by which time the information may be irrelevant. Penalty clauses are far from onerous. At worst, a non-complying employer is faced with possible legal action on an implied term of contract. The CAC has also expressed disquiet at the enforcement machinery. In one case where the employer had not complied with a disclosure ruling, the CAC felt unable to include the information in individual employment contracts: "We were presented with something of a problem as there can be important differences between information necessary for effective collective bargaining and information suitable 
for inclusion in an individual's contract of employment" (Holokrome Ltd and ASTMS 1979).

(d) Constraints on the use of information - the ACAS code recognises that disclosure rights depend for their effectiveness upon the abilities of the negotiators to understand and use the information concerned. Hussey and Marsh (1983) conclude that this is probably "the most doubtful part of the process". Gold et al. (1979) identify a series of constraints upon the use of information arising from managerial attitudes, industrial and organisational structures and problems in union servicing, policy and structure. Union representatives may, for example, feel ill-equipped to deal with financial information as a result of inadequacies in the provision of research and training facilities.

\section{Disclosure legislation - a move towards pluralism?}

In the United Kingdom and United States, the primary emphasis has been on disclosure for the purposes of collective bargaining. NLRA and TULRCA provisions imply parliamentary acceptance of a pluralist perspective; there is recognition of a conflict of interests between management and labour which needs to be negotiated and compromised. However, as is clear from the above review, unitarist reasoning is evident in many of the judicial interpretations. Decisions have by and large reinforced notions of managerial and capital prerogatives. The courts have been reluctant to substitute their own judgments for management opinions, preferring to endorse the "best" practices of employers. Managers are regarded as having a right to make strategic decisions without notification or consultation (either as agents of "owners" or because of their technical expertise). Where information rights are recognised management still has control over the information that is to be collected and may determine the form in which it is presented. There is a reluctance to enforce disclosure of information which reveals or confirms conflicts of interest. Unions are not trusted to preserve confidentiality. As a result disclosure rights have not been extended as far as might originally have been expected. The European approach to disclosure, by contrast, reflects a more explicit pluralist "stakeholder" approach, with greater commitment to the philosophy of worker rights to consultation and participation in the management of organisations.

\section{Europe}

Works council schemes with statutory provisions for disclosure have operated in most European countries since the 1940s (British Institute of Management, 1957). This section focuses on the disclosure rights of Belgium works council representatives (Blanpain, 1992; National Labour Consultative Council 1988) which are specified in greater detail than in many other European countries. However, broadly similar rights are conferred by law in Austria, France, Germany, Luxembourg and the Netherlands (ibid). 
In Belgium works councils are mandatory in all enterprises normally employing at least 100 workers. Such councils, composed of employee and up to an equal number of employer representatives, must have at least four employee members in undertakings with 100 employees, rising to 22 members in undertakings with more than 8,000 employees. Under a 1973 Royal Order, the employer is obliged to provide works council members with sufficient financial and economic information to give them "a clear and accurate" view of the undertaking and the legal, economic and financial entities of which it is a part. Where the enterprise comprises separate production centres, relevant information must also be provided with respect to these sub-units. The required disclosures comprise four major categories: basic information, annual information, periodic information and occasional information. Any documents given to shareholders must also be provided to works council members.

(a) Basic information - detailed information must be given to works council members within two months of their election or re-election on the legal status of the undertaking, its competitive position, production and productivity levels, financial structure, budgets and cost structures, labour costs, investment plans and future prospects, research programme, state financial assistance and basic organisational structure.

(b) Annual information - within three months of the end of the financial year and before the annual general meeting of shareholders, information must be given on financial results for the past year, the utilisation of tax and financial incentives, a comparative analysis of objectives and achievements, economic and financial objectives for the coming year and future profit and employment prospects. Balance sheet and profit and loss account information must be compared with results from the two previous years and an analysis provided of changes in capital, reserves, debt levels, fixed and current assets, depreciation taken, income and expenditure levels, profit distributions and managerial and nonmanagerial remuneration. Detailed explanation of any changes in accounting policy must also be supplied.

(c) Periodic information - information must be supplied at least every three months on sales forecasts, order-book situation, costs, price changes, stock levels, productivity and employment, the use being made of any state aid received, budgetary control and the meeting of objectives. This information is intended to enable works council members to make a judgement on the attainment of organisational objectives and must be in a form which enables proper comparisons with basic and annual information.

(d) Occasional information - whenever events occur or internal decisions are being taken that could have "major implications" for the undertaking, information relating to the expected effects on the undertaking's activities and the employee's situation is to be supplied. Information should, wherever possible, be communicated before decisions take effect.

The Royal Order emphasises that information supplied to works council members must be the "occasion of an exchange of views". Members have the right to "ask for additional information, 
put questions, make criticisms and suggestions and voice opinions". To ensure continuity of dialogue, heads of undertakings must state what action they intend to take with regard to questions, criticisms, suggestions or objections put forward.

Auditors are required to report annually to the works council on the annual accounts and to certify the "truth and completeness" of the economic and financial information communicated. Experts can also be invited to attend works council meetings by either management or labour. The other party has the right to refuse the expert but may not use this right more than twice in a period. If disagreement persists, there is a right of appeal to the Ministry of Economic Affairs. Employee representatives are also entitled to attend union-organised labour education programmes on full pay for the purpose of developing their own expertise.

Employers can avoid certain specified categories of disclosures on the grounds of "harm to the undertaking" but few companies are reported to do so (Hilton, 1978). Such dispensations are subject to prior approval by the Department of Commerce. Employee works council members are assigned the task of informing staff of the undertaking on the basis of the information communicated to them "taking care to use it with all the discretion necessary to safeguard the undertaking's interests".

Concern has been expressed about the level of compliance with the provisions of the Royal Decree. Jain (1978), for example, reports a survey which found that about one half of the firms surveyed provided the necessary information and "two-thirds of the remainder were deficient on technical grounds: inadequate documentation, late information, no special meetings". Nonetheless, European disclosure practices are well ahead of those in the United Kingdom and United States.

European unions also have extended rights of access to information and opportunities to influence the external financial reporting process through the two-tier system of company boards. In Germany, for example, the supervisory board (Aufsichtsrat), which oversees the course of business and which includes both employee and union representatives (on certain industry and size criteria), approves the annual reports and examines board of management proposals for the appropriation of profits. Any member of the supervisory board can request, at any time, information on affairs of importance for the enterprise. The management board has a statutory duty to meet such requests.

\section{European union}

In 1980 the European Commission issued a draft Directive - the "Vredeling" Directive - seeking to more clearly define employee rights to information and consultation in undertakings with complex structures, in particular multinational enterprises. The Directive proved highly controversial and was amended substantially in an attempt to get the support of both management and labour interests in various member countries. A modified version of the Directive went 
before the Council of Ministers in 1983. In 1986 the Council requested the Commission to resume discussions about Vredeling in 1989 , to review the development of disclosure legislation in member states during the intervening period and to encourage further dialogue between employer and employee organisations. In 1990 the Commission issued a draft Directive on the establishment of European Works Councils (EWCs) containing broadly similar information and consultation requirements to those in Vredeling. The United Kingdom Government remained opposed in principle to the proposals and in 1993 the Commission relaunched talks under the 11State-only social policy procedures established by the Maastricht Treaty. Following the failure of European-level trade union and employer organisations to negotiate an agreement on the issue, the Commission submitted a modified version of the EWC Directive as a formal legislative proposal to the Council of 11 (the United Kingdom excluded).

A final version of the 11-State Directive was adopted in 1994, for implementation by September $1996^{6}$. The main provisions of the Directive are as follows:

(a) Scope and aims of the Directive - the Directive provides a framework for the establishment of EWCs or other procedures for informing and consulting employees in undertakings (and groups of undertakings) employing at least 1,000 employees within the member states and 150 or more employees in each of at least two member states. Negotiations over the establishment of EWCs or other procedures may be initiated by management or at the request of 100 employees or their representatives. This involves the establishment of a "special negotiating body" (SNB), made up of employee representatives, which is to negotiate an agreement with management. Unless the SNB decides (by a two-thirds majority) not to initiate or continue negotiations, this process must result in an agreement on an EWC or other procedure within three years of the request for negotiations. If not, or if management refuses to commence negotiations, a minium set of information and consultation requirements (referred to as the "subsidiary requirements") applies. The Directive does not apply to groups and undertakings where, by September 1996, "there is already an agreement, covering the entire workforce, providing for the transnational information and consultation of employees".

(b) Subsidiary requirements - the subsidiary requirements, which apply where management and workers cannot reach a voluntary agreement, require the establishment of an EWC and set out a number of rules on its competence, composition and operation. At least once a year, the EWC has the right to meet with central management, to be informed and consulted on the progress of the organisation's business and its prospects. Information

For further details on the Directive's background and an analysis of the major differences between the EWC proposals and "Vredeling", see European Industrial Relations Review (EIRR, 1991; 1994a, b and c). Since the Directive was adopted Austria, Finland and Sweden have joined the European Union. Iceland, Liechtenstein and Norway are also bound by the Directive through the European Economic Area Agreement, bringing the total of countries covered to 17 . 
must refer to: the organisation's structure; its economic and financial situation; the probable development of the business and of production and sales; the employment situation and probable trends; investments and substantial changes concerning orgahisation (including the introduction of new work methods or production processes, transfers of production, mergers, cut-backs or closures and collective redundancies).

Where there are "exceptional circumstances" affecting the employees' interests to "a considerable extent" - particularly in the event of relocations, closures or collective redundancies - employee representatives have the right to meet management with a view to being informed and consulted on any measures significantly affecting employees' interests. The meeting must be timely and be based on a report from management on which the EWC may give an opinion. It is stressed, however, that the meeting will not affect the prerogatives of central management.

The operating expenses of the EWC are to be met by central management, which must provide members with the financial and material resources necessary for them to carry out their duties appropriately. The EWC may also be assisted by experts of its choice, insofar as this is necessary for it to carry out its tasks. Member states may lay down budgetary rules regarding the operation of the EWC and, in particular, limit funding to cover one expert only.

(c) Confidential information - central management is not obliged to transmit information if this would "seriously harm" or prejudice the undertaking concerned. However, these confidentiality exemptions are only to apply in specific cases and under conditions and limits laid down by national legislation. Member states may also make such dispensation subject to prior administrative or judicial authorisation.

(d) Disputes and enforcement - member states are to provide for "appropriate measures" in the event of failure to comply with the Directive. In particular, adequate administrative or judicial procedures must be available to enable obligations derived from the Directive to be enforced. Where member states allow management to restrict or withhold information on confidentiality grounds, they must ensure administrative or judicial appeal procedures are available to employees.

The Directive's proposals have been the subject of considerable debate between the European Trade Union Confederation (ETUC) and European private sector employers (see, for example, Pipkorn, 1983; Hussey, 1984 and EIRR, 1991). ETUC favours greater transparency of multinational activities through mandatory, legal procedures for the disclosure of information. It has expressed concern at the "watering down" of the Directive through various modifications to the original draft and is also concerned about the issue of enforcement. Employer interest groups, on the other hand, argue that mandatory procedures would be unworkable for the separate member states, present a threat to managerial prerogatives, create problems regarding the confidential nature of information and take no account of "economic necessities". United 
Kingdom employers, in particular, have urged that the matter is best left to the establishment of voluntary codes. When the amendments to the "Vredeling" Directive were tabled, a Confederation of British Industry spokesperson commented that although they "were a step in the right direction they did not make the direction any more palatable" (Hussey and Marsh, 1983: 58). Concern has also been expressed that the proposals will lead to "capital flight". Lyall (1984: 63), for example, reports that the Japanese threatened to stop investing in the European Community if the "Vredeling" proposals were implemented.

Four months out from the Directive's implementation date, the number of voluntary agreements between management and workers stood at approximately 100 (covering more than 1,100 companies), while virtually all the affected countries had taken steps to implement the Directive at national level (either through collective agreements between central trade union and employer organisations or the introduction of draft legislation); see EIRR (1996) for details. Unions have expressed misgivings about a number of aspects of the voluntary agreements, with some arrangements being regarded as attempts to avoid setting up "real" EWCs (EIRR, 1995a; 1995b). More recently, various European-level union bodies have issued guidelines for the negotiation of EWC agreements including specification of "bottom line" conditions. The ETUC has also issed a "protocol of procedures", aimed at preventing disputes between unions (EIRR, 1996).

\section{Conclusions}

By comparison with their overseas counterparts, New Zealand workers and unions are not well served with respect to the regulated disclosure of financial information. In this paper, the New Zealand situation, where employers are under no statutory duty to supply any financial information to labour representatives, has been contrasted with the situation existing in the United States, United Kingdom and throughout Europe. In the United States rights to "relevant and necessary information" arise out of the employer's statutory duty to bargain in good faith. In the United Kingdom, employers are obliged to disclose information without which union representatives would be materially impeded from carrying out their collective bargaining duties and which it would be in accordance with "good industrial relations practice" to disclose. Throughout Europe statutory provisions at national and Community level impose duties on employers to supply works councils and worker representatives on company boards with a range of financial information.

Clearly any disclosure system will be firmly embedded in the socio-political framework of the territory concerned and may not translate easily. Nonetheless, labour interests in all countries tend to share many of the same concerns, for example, about corporate accountability, the ability to bargain in an informed manner, the importance of consultation and participation in issues that materially affect them and monitoring the efficiency and equity of managerial decision-making. Current trends under the Employment Contracts Act towards enterprise and productivity bargaining provide one of the more obvious starting points for unions and others interested in developing disclosure practice in New Zealand. The issue of information rights also deserves 
high priority on any agenda concerning "workplace reform". In either case, overseas legislation provides a useful reference base. Some valuable lessons may also be drawn from overseas experiences concerning the importance of ensuring that legislative or contractual exemptions are not so widely drawn as to allow determined employers to refuse to disclose anything (or to provide disclosure only when it suits them), the need for disclosure education if labour representatives are to be in a position to use information effectively, the importance of their being able to gain some assurance about the credibility of the data supplied and the need for adequate enforcement machinery. The review of United States and United Kingdom legislation also highlights the significance of judicial decision-making and the potential for judges to subvert or at least reduce the impact of pluralist provisions through the (conscious or unconscious) application of unitarist reasoning to issues of interpretation.

\section{References}

Atleson, J.B. (1983), Values and Assumptions in American Labor Law, Massachusetts, University of Massachusetts Press.

Bartosic, F. and Hartley, R.C. (1972), The Employer's Duty to Supply Information to the Union a Study of the Interplay of Administrative and Judicial Rationalization, Cornell Law Review, 58: 23-50.

Blanpain's International Encyclopedia of Labour Law and Industrial Relations, Netherlands, Deventer.

British Institute of Management (1957), Presenting Financial Information to Employees, London, BIM.

Brown, J. (1992), Accounting to the Workforce, NZ Journal of Industrial Relations, 17(2): 20722.

Burchell, S., Clubb, C. and Hopwood, A. (1985), Accounting in its Social Context: Towards a History of Value Added in the United Kingdom, Accounting, Organizations and Society, 10(4): 381-413.

Central Arbitration Committee (1978), Annual Report, London, HMSO.

Clark, H. (1993), Employment Relations - the New Direction Under Labour, NZ Journal of Industrial Relations, 18(2): 153-62.

Commission on Industrial Relations (1972), Disclosure of Information, London, HMSO. 
Dair, P. and Reeves, T.K. (1979), Why Disclosure Could be a Non-Event, Personnel Management, 11(1): 24-7.

Dickens, L. (1980), Disclosure of Information to Trade Unions in Britain, SSRC Industrial Relations Research Unit, University of Warwick, Coventry.

European Industrial Relations Review (1991), The EWCs Directive and Previous Participation Initiatives, 207: 23-7.

European Industrial Relations Review (1994a), European Works Councils Directive, 251: 27-32.

European Industrial Relations Review (1994b), European Works Councils - the Action Begins, 250: $14-7$.

European Industrial Relations Review (1994c), European Information and Consultation Draft Directive, 244: 28-32.

European Industrial Relations Review (1995a), EWCs Latest, 255: 4.

European Industrial Relations Review (1995b), European Works Councils Update - Trends and Issues, 256: 14-22.

European Industrial Relations Review (1996), EWCs - the Deadline Approaches, 268: 15-6.

Foley, B.J. and Maunders, K.T. (1977), Accounting Information Disclosure and Collective Bargaining, London, Macmillan.

General and Municipal Workers' Union (1978), Disclosure of Information, London.

Goggans, T.P. (1964), The Accountant's Role in Wage Negotiations, Accounting Review, July: 627-30.

Gold, M., Levie, H. and Moore, R. (1979), The Shop Stewards' Guide to the Use of Company Information, Nottingham, Spokesman.

Gospel, H. and Willman, P. (1981), Disclosure of Information: The CAC Approach, Industrial Law Journal, 10: 10-22.

Harvey on Industrial Relations and Employment Law (1991), London, Butterworths.

Hilton, A. (1978), Employee Reports: How to Communicate Financial Information to Employees, Cambridge, Woodhead-Faulkner. 
Hussey, R. (1984), Vredeling Ready to Spring Trap on the Unwary, Accountancy, 95(1086): 75-6.

Hussey, R. and Marsh, A. (1983), Disclosure of Information and Employee Reporting, UK, Gower.

Industrial Relations Review and Report (1992), 92: 16.

Industrial Relations Review and Report (1993), 93: 16.

Jackson-Cox, J., McQueeney, J. and Thirkell, J.E.M. (1987), Strategies, Issues and Events in Industrial Relations, London, Routledge and Kegan Paul.

Jain, H.C. (1978), Information, Training and Effective Participation, Industrial Relations Journal, 9(1): 48-60.

Jain, H.C. (1981), Disclosure of Corporate Information to Trade Unions in North America, Relations Industrielles, 36(4): 748-71.

Lyall, D. (1984), Compulsory Disclosure to Employees - the Vredeling Directive, The Accountant's Magazine, 88(932): 61-3.

Marsh, A. and Hussey, R. (1980), Disclosure to Unions - How the Law is Working, Touche Ross and Co.

Marsh, A. and Rosewell, R. (1976), A Question of Disclosure, Industrial Relations Journal, 7(2): 4-16.

National Labour Consultative Council (1988), Guidelines on Information Sharing, Canberra.

NZ Business Roundtable (1989), Industrial Democracy: A Case for Regulation or Deregulation?, A Submission to the Committee of Inquiry into Industrial Democracy, Wellington.

NZ Council of Trade Unions (1989), Submission to the Industrial Democracy Committee of Inquiry, Wellington.

NZ Employers' Federation (1989), Submission to the Committee of Inquiry on Industrial Democracy, Wellington.

NZ Law Commission (1987), Company Law, Preliminary Paper 5, Wellington.

NZ Law Commission (1989), Company Law: Reform and Restatement, Wellington. 
NZ Society of Accountants (1993), Statement of Concepts for General Purpose Financial Reporting, Wellington, NZSA.

Owen, D.L. and Harte, G.F. (1984), Reporting on Corporate Accountability to the Workforce, Accountant's Magázine, 88(935): 184-7.

Palmer, J.R. (1977), The Use of Accounting Information in Labor Negotiations, New York, National Association of Accountants.

Pipkorn, J. (1983), The Draft Directive on Procedures for Informing and Consulting Employees, Common Market Law Review, 20: 725-55.

Report of the Committee of Inquiry into Industrial Democracy (1989), Department of Labour, Wellington.

Smith, A. (1985), Employee Reporting in New Zealand, MCA Thesis, Victoria University of Wellington.

Storey, J. (1992), Developments in the Management of Human Resources, Oxford, Blackwell.

Townley, B. (1989), Employee Communication Programmes. In Sisson, K. (ed.), Personnel Management in Britain, Oxford, Blackwell.

Trades Union Congress (1974), Industrial Democracy, London, TUC.

Trade Union Congress (1977), The Trade Union Role in Industrial Policy, London, TUC.

Trades Union Congress (1987), Profit Related Pay, London, TUC.

Trades Union Congress-Labour Party Liaison Committee (1982), Economic Planning and Industrial Democracy, London, Labour Party.

\section{Cases}

Airwork Services Ltd and the Amalgamated Union of Engineering Workers (1978) CAC Award $78 / 584$.

Cincinnati Cordage and Paper Co. (1963) 141 NLRB 72.

Clydesdale Bank Ltd and the Association of Scientific, Technical and Managerial Staffs (1978) CAC Award 78/277. 
Daily Telegraph Ltd and the Institute of Journalists (1978) CAC Award 78/353.

Detroit Edison Co. v NLRB (1979) 440 US 320.

Fibreboard Paper Products Ltd v NLRB (1964) 379 US 203, 223.

Greater London Council and the Greater London Council Staff Association and the Union of Construction, Allied Trades and Technicians (1979) CAC Award 79/470.

Holokrome Ltd and the Association of Scientific, Technical and Managerial Staffs (1979) CAC Award 79/451.

Hoover Ltd and the General and Municipal Workers Union (1979) CAC Award 79/146.

International Woodworkers of America v NLRB (1959) 263 F.2d 483.

Jacobs Manufacturing Co. (1951) 94 NLRB 1214.

McLean-Arkansas Lumber Co. (1954) 109 NLRB 157.

NLRB v Truitt Manufacturing Co. (1956) 351 US 149.

Old Line Life Insurance Co. (1951) 96 NLRB 499.

Standard Telephone and Cables Ltd and the Association of Scientific, Technical and Managerial Staffs (1979) CAC Award 79/484.

Whitin Machine Works (1955) 108 NLRB 1537.

Yakima Frozen Foods (1961) 130 NLRB 1269. 